\title{
Nutrients in Amazonian Black Earth from Caxiuanã Region
}

\author{
Vanda P. Lemos, ${ }^{*}, a$ Antônio R. de Oliveira Meireles, ${ }^{a}$ Kelly das Graças Fernandes, ${ }^{a}$ \\ Milena C. de Moraes, ${ }^{a}$ Marcondes L. da Costa, ${ }^{b}$ Any K. Terra Silva ${ }^{b}$ and Dirse C. Kern ${ }^{c}$ \\ Instituto de Ciências Exatas e Naturais and ${ }^{b}$ Instituto de Geociências, \\ Universidade Federal do Pará, 66075-110 Belém-PA, Brazil
}

${ }^{c}$ Museu Paraense Emilio Goeldi, Belém-PA, Brazil

\begin{abstract}
Padrões de dispersão de nutrientes em terra preta Amazônica (TPA) podem dar informações sobre atividades antrópicas dos habitantes da Amazônia. Estudos sobre pH, fósforo

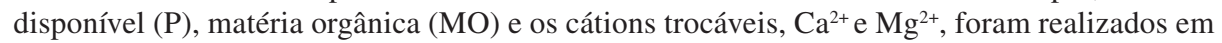
amostras de solos dos horizontes $\mathrm{A}_{1}$ e $\mathrm{A}_{2}$ ao longo de uma área com TPA (norte-sul e lesteoeste) em um sítio arqueológico denominado Ilha de Terra, na Unidade de Conservação Floresta Nacional de Caxiuanã, Município de Melgaço, Brasil. Os resultados indicaram que a MO e o Ca são os que apresentam maior dispersão. Correlações mais elevadas foram encontradas entre $\mathrm{OM}-\mathrm{Ca}-\mathrm{Mg}$ às proximidades da área central e levam a inferir que a dispersão geoquímica de MO, $\mathrm{Ca}, \mathrm{Mg}$ e $\mathrm{P}$ em sítios arqueológicos com TPA está relacionada com atividades humanas pregressas.
\end{abstract}

Dispersion of nutrients in Amazonian black earth (ABE) can provide information on human activities of the inhabitants of the Amazon region. Studies on the $\mathrm{pH}$, available phosphorus (P), organic matter $(\mathrm{OM})$ and the exchangeable cations $\mathrm{Ca}^{2+}$ and $\mathrm{Mg}^{2+}$ were performed on soil samples from horizons $\mathrm{A}_{1}$ and $\mathrm{A}_{2}$ over an area with TPA (north-south and east-west) at a site called Ilha de Terra, located in the Conservation Unit Caxiuanã National Forest, Melgaço County, Brazil. The results indicated that the $\mathrm{OM}$ and $\mathrm{Ca}^{2+}$ are the ones with greater dispersion. Higher correlations were found between $\mathrm{OM}-\mathrm{Ca}-\mathrm{Mg}$ to near the central area. This leads to the inference that the dispersion geochemistry of $\mathrm{MO}, \mathrm{Ca}, \mathrm{Mg}$ and $\mathrm{P}$ in archaeological sites with TPA is related to past human activities.

Keywords: nutrients, Caxiuanã, soils, Amazonian black earth

\section{Introduction}

Chemical, mineralogical and micromorphological analysis can be used to interpret human activities from material remains in soils. The abandonment of human activities in settlements does not affect chemical residue remains in soils. The potential validity of the chemical analysis of soil to interpret archaeological finds lies in its ability to predict significant features based on $(i)$ the chemical signatures of total concentrations of multielements such as $\mathrm{Ba}, \mathrm{Ca}, \mathrm{P}, \mathrm{Zn}, \mathrm{Cu}$ and $\mathrm{Pb}$ in soils; ${ }^{1}$ (ii) the chemical signatures of floor samples in the Maya region; ${ }^{2,3}$ (iii) the available nutrients in soils from the Brazilian Amazon basin, ${ }^{4-8}$ known by designations such

*e-mail: vplemos@ufpa.br as black earth, Indian black earth, anthropogenic black earth, archaeological black earth, Amazonian black earth $(\mathrm{ABE})^{9,10}$ or Amazonian dark earths. ${ }^{11,12}$ The area in which $A B E$ occurs is characterized by well-drained soil, running water and located in a particular geographical setting from which the surrounding areas can be clearly observed. ${ }^{9}$

$\mathrm{ABE}$ is a soil that can be distinguished from other soils from the Brazilian Amazon because of its high content of $\mathrm{Ca}, \mathrm{Mg}, \mathrm{Zn}, \mathrm{Mn}, \mathrm{P}$ and $\mathrm{C}$ due to the incorporation of bones and organic matter $(\mathrm{OM})$. The high level of organic matter in $A B E$ is attributed to the time of human occupation of the site. ${ }^{10-13}$ According to the soil classification system, ABE sites can be found on several soil classes, such as Oxisols, Ultisols, Inceptisols, Latossolos, Argissolos, Cambissolos, Plintossolos, Espodossolos, Fimic Anthrosols and others. ${ }^{14}$ 
In Latossolos, the organic component is derived from the natural vegetal covering, whereas in ABE the organic component is principally derived from the debris of human occupation. These highly fertile micro-ecosystems formed in the past seem not to exhaust their chemical content in conditions of tropical forest. ${ }^{6}$ The association between soil nutrient level and availability is dependent on the extraction used to determine the nutrient level, soil water regime, physical and chemical soil characteristics controlling nutrient movement and the ability of the plant or plants in question to use the nutrient when it reaches the surface. Nutrient bioavailability is a function of the release of nutrients from their inorganic or organic solid phases, followed by their movement through the soil solution to the roots or fungi, with an ensuing uptake in plant available form. ${ }^{7}$

In the field, ABE soils are identified by unusual features for Amazonian upland soils, such as top soils with dark matrix colors (dark brown to black), the presence of lithic artifacts and pyrogenic carbon.9,15 The occurrence of ceramics and black carbon indicates that the genesis of these soils is strongly linked to anthropogenic processes. ${ }^{12,16}$ Several terms are used synonymous with black carbon, such as charcoal, soot, elemental carbon or pyrogenic carbon. Black carbon has been proposed to be an important sink in the global carbon cycle. ${ }^{15-18}$ Information on the chemical properties and biological stability of black carbon in soil is limited and more research is needed in this area.

The most accepted theory on the origin of ABE is the anthropogenic evidence demonstrated through the activities of prehistoric humans. The observations of Neves et al. ${ }^{19}$ indicate that the social practices in settlements with $\mathrm{ABE}$ are still not fully understood and that ABE formation was a faster process than previously thought. The increase in population according to the weather could provide an explanation on the formation of ABE but this has not been indicated in sites with multiple occupations. Further research might explain the abandoned settlements in the central Amazon.

Chemical and mineralogical studies on ABE can evaluate the anthropogenic impact on the original soils. An evaluation of the dispersion of nutrients in an area with $\mathrm{ABE}$ has been made in this paper. The selected ABE site is called Iha de Terra, located in the area of research called Estação Científica Ferreira Penna (ECFPn), within the National Forest of Caxiuanã (NF-Caxiuanã), belonging to the cities of Portel and Melgaço-Pará in the Amazon region. ${ }^{20}$

\section{Study area}

The national forest of Caxiuanã (NF-Caxiuanã) is located on the west side of the Bay of Caxiuanã downstream of the Anapu River and the bank of the Xingu River, and includes the cities of Portel and Melgaço in the lower Amazon. NF-Caxiuanã is administered by the Brazilian Institute for Environmental Monitoring (IBAMA) and is protected by the National System of Conservation of Nature from the federal government. The ECFPn built inside the reserve and belonging to the Museu Paraense Emílio Goeldi (MPEG) supports multidisciplinary research on natural sciences. Access to the area is in two steps: the first through the waterway between the cities of Belém and Breves (Ilha do Marajó), lasting for $12 \mathrm{~h}$; the second stage is also a waterway. The journey in this step is made by boat to the ECFPn and passes Hole Breves, the Bay of Melgaço, Anapu river basin toward the source of the river (duration of 9 h), Bay of Caxiuanã, Curuá River until reaching the Trapiche-ECFPn. The area of ECFPn (33,000 hectares) is located north of NF-Caxiuanã and is surrounded by a dense forest area, which ensures optimal conditions for its conservation. Around the edges of the Bay of Caxiuanã, 27 archaeological sites with ABE were discovered. The archaeological site Ilha de Terra is located near the Hole Camuim. Ancient inhabitants of the cities of Portel and Melgaço were the Indians Arucará and Aricuru (also called Guaricuru, Uaricuri or Ingaíbas), respectively. Currently, some families are found near the rivers but they do not cause damage to the environment because they preserve the habits of prehistoric man. ${ }^{21}$

\section{Experimental}

\section{Soil sampling}

The ABE area was delimited from the yellow Latossolos surrounding (YLS). East-west and north-south base lines were traced by auxiliary lines with $10 \mathrm{~m}$ spacing for sampling. The sampling was carried out along the ABE area (Figure 1), between two soil profiles (YLS profile and ABE profile), following the methods of Lemos and Santos. ${ }^{21}$ The horizons of the soils were classified according to the methods of the Brazilian System of Soil Classification and color samples were determined according to Munsell collors. ${ }^{23}$

\section{Soil analysis}

Samples (fractions $<2 \mathrm{~mm}$ ) of air-dried soil were used in the particle size distribution of the bulk soil, morphological, mineralogical and chemical analysis. Particle size distribution was determined using the sieve/ pipette method after ultrasonic dispersion in $\mathrm{NaOH}$ $0.01 \mathrm{~mol} \mathrm{~L}^{-1}$. Morphologies and surface textures of black 


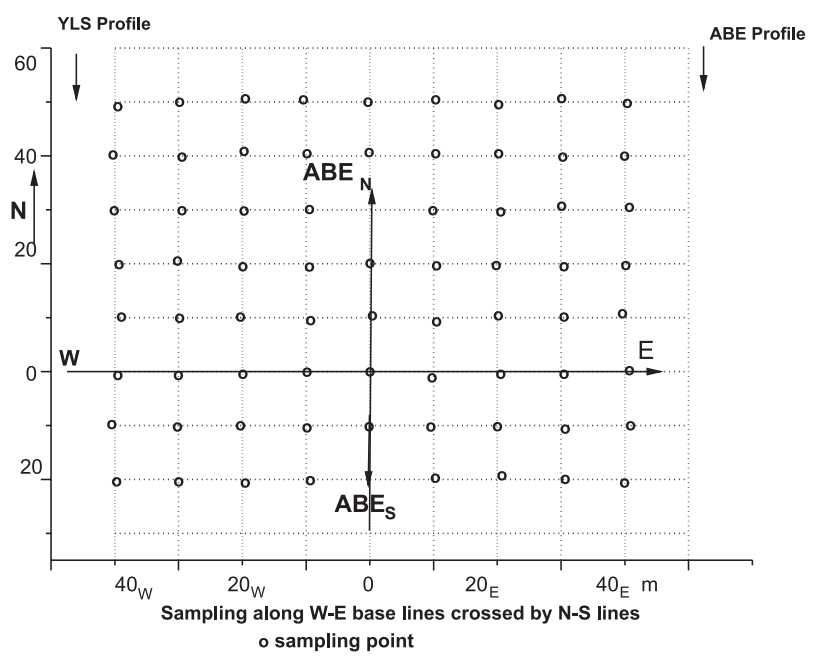

Figure 1. Sampling in ABE area from Ilha de Terra. The ABE area was delimited from the yellow Latossolos surrounding (YLS). East-west and north-south base lines were traced by auxiliary lines with $10 \mathrm{~m}$ spacing for sampling.

carbon were examined by scanning electron microscopy (SEM), from thin layers of samples sputtered with $\mathrm{Pt}$ to enhance the surface conductivity. SEM analysis was performed under conditions of images obtained by electron backscattering at $20 \mathrm{kV}$, with a distance of work of $14 \mathrm{~mm}$. Mineralogical analysis was carried out by X-ray diffraction (XRD) using a Philips X-ray diffractometer (PW-1050) with monochromatic $\mathrm{Cu}-\mathrm{K} \alpha$ radiation. The following chemical analysis were carried out according to the soil survey laboratory methods manual from USDA: ${ }^{24}$ potentiometric measures of $\mathrm{pH}$ (in $\mathrm{H}_{2} \mathrm{O}$ and $\mathrm{KCl}$ ), concentrations for available $\mathrm{P}$, exchangeable $\mathrm{Ca}^{2+}$ and $\mathrm{Mg}^{2+}$ and the total concentrations for organic $\mathrm{C}, \mathrm{Si}$, $\mathrm{Al}$ and Fe. Suitable extractors were used in the analysis of available $\mathrm{P}$ and exchangeable cations ions to replace or promote the selective dissolution of ions on the surface of minerals and organic substances. Exchangeable $\mathrm{Ca}^{2+}$ and $\mathrm{Mg}^{2+}$ were extractable with the $\mathrm{KCl}$ solution ( $1 \mathrm{~mol} \mathrm{~L}^{-1}$ ) and the available $\mathrm{P}$ with the extractor Mehlich-1 ( $\mathrm{HCl} 0.05 \mathrm{~mol} \mathrm{~L}^{-1}$ plus $\mathrm{H}_{2} \mathrm{SO}_{4} 0.0125 \mathrm{~mol} \mathrm{~L}^{-1}$ ). Concentrations of exchangeable $\mathrm{Ca}^{2+}$ and $\mathrm{Mg}^{2+}$ were measured by atomic absorption spectrometry and the available $\mathrm{P}$ by spectrophotometry $(\lambda=860 \mathrm{~nm})$ as a blue heterocompound from the reduction of heteropolyacid molybdophosphoric. ${ }^{25}$

The measurement total organic carbon (TOC) can help the indirect analysis of OM formed during the decay of plant and microbial residues, either by selective preservation and the transformation of constituents resistant to biodegradation and aliphatic polymers, or by the condensation of low-molecular-weight degradation products such as phenols, phenolic acids and amino acids. ${ }^{26,27}$ TOC was determined by Walkley-Black modified acid-dichromate digestion and $\mathrm{FeSO}_{4}$ titration. TOC values were multiplied by the Van Bemmelen factor of 1.724 to calculate OM. Black carbon is not determined by the Walkley-Black method, but its presence was investigated by macroscopic observations and SEM analysis.

Total concentrations for $\mathrm{Si}, \mathrm{Al}$ and $\mathrm{Fe}$ were determined using the alkaline fusion method after the dissolution of the sample melted in $\mathrm{HCl}$ solution, evaporation of the acid solution, treatment of the residue from this evaporation with concentrated $\mathrm{HCl}$ to precipitate silica, filtration (solution A) and separation of the precipitate, treatment of the precipitate with a mixture of $\mathrm{H}_{2} \mathrm{SO}_{4}: \mathrm{HF}(1: 200)$, calcination and weighing the final residue. Solution A was used to measure the concentrations of $\mathrm{Al}$ and $\mathrm{Fe}$ by AAS-flame.

The significance of the variability of the chemical elements and correlation coefficients for these elements from the ABE area was evaluated by analysis of variance of values (F) and correlation matrix, respectively. The variance values were determined for the CCABE areas north, south, central, north-south and west-east, indicated in this study as $\mathrm{ABE}_{\mathrm{N}}, \mathrm{ABE}_{\mathrm{S}}, \mathrm{ABE}_{\text {central }}, \mathrm{ABE}_{\mathrm{N}-\mathrm{S}}$ and $\mathrm{ABE}_{\mathrm{W}-\mathrm{E}}$, respectively.

\section{Results and Discussion}

\section{The soil horizons}

The following horizons were observed in the $\mathrm{ABE}$ profile: $A_{1}$ and $A_{2}$ black (0-7 cm and 7-14 cm, respectively), $\mathrm{A}_{3}$ dark brown (14-29 cm), AB dark grayish brown $(29-57 \mathrm{~cm})$, BA brown $(57-89 \mathrm{~cm})$ and $B_{1}, B_{2}$ and $B_{3}$ brownish yellow (89-110, 110-135 and 135-161 cm, respectively). The YLS profile presents the following: $A_{1}$ horizon dark grayish brown $(0-8 \mathrm{~cm}), \mathrm{AB}$ and $\mathrm{BA}$ horizons brownish yellow (8-20 and 20-59 cm, respectively) and $B_{1}$, $\mathrm{B}_{2}$ and $\mathrm{B}_{3}$ horizons dark yellowish Brown (59-100, 100-162 and $162-180 \mathrm{~cm}$, respectively).

\section{Physical and chemical properties}

The high OM, available $\mathrm{P}$, exchangeable $\mathrm{Ca}^{2+}$ and $\mathrm{Mg}^{2+}$ content (Tables 1-3) and frequent occurrence of $\mathrm{BC}$ are diagnostic attributes of anthropogenic soils. BC occurs in the forms of irregular fragments micrometer to millimeter and fibrous texture (Figure 2). Studies on BC in soils from other sites have shown great variability in sizes, shapes and chemical composition of particles of BC. It has also been found numerous particles of $\mathrm{BC}$ in the medium density fraction indicating organ-mineral complexes and the distribution of $\mathrm{BC}$ across aggregate fractions in close contact with minerals. ${ }^{28-31}$ 

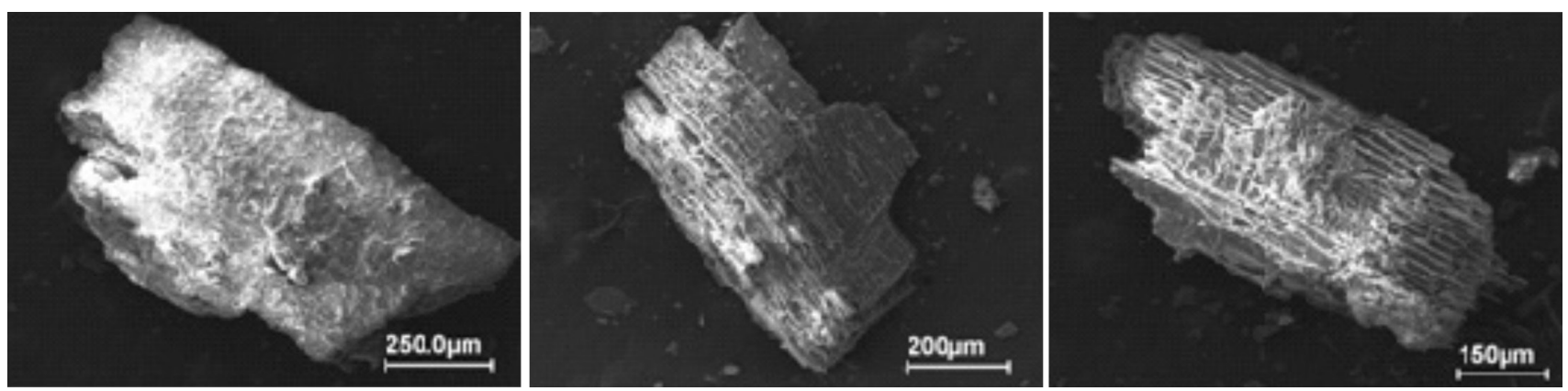

Figure 2. Fragments of black carbon with micrometer dimensions, irregular shapes and fibrous texture from $\mathrm{A}_{1}$ horizon-ABE soil profile.

The physical and chemical properties in the soil profiles from ABE and YLS shows that the main differences between the two soil profiles are observed in the upper horizons of the soil profiles (Table 1 and Figure 3). Particle size distribution indicates a predominance of coarse sand fraction on the other fractions in soil profiles ABE and YLS, and this allows the identification of the types of textures. In the $\mathrm{ABE}$ profile, the texture is sandy in $\mathrm{A}_{1}$ to $\mathrm{BA}$ and sandy-clay in $\mathrm{B}$, whereas in the YLS profile the. Data from $\mathrm{X}$-ray diffraction show that the horizons $\mathrm{A}_{1}$ of soil profiles $\mathrm{ABE}$ and YLS have quartz as main mineral. Reflections of kaolinite were identified only in the soil profile YLS (Figure 3). Anatase, goethite and or hematite were not identified because they must occur at low frequencies, given the low concentrations of Ti and Fe obtained in these soils.

From the total concentrations of $\mathrm{SiO}_{2}, \mathrm{Al}_{2} \mathrm{O}_{3}, \mathrm{Fe}_{2} \mathrm{O}_{3}$ and $\mathrm{OM}$ (Table 1) it was estimated the concentrations of the minerals and organic matter in both soil profiles. It was verified that kaolinite and quartz are the predominant

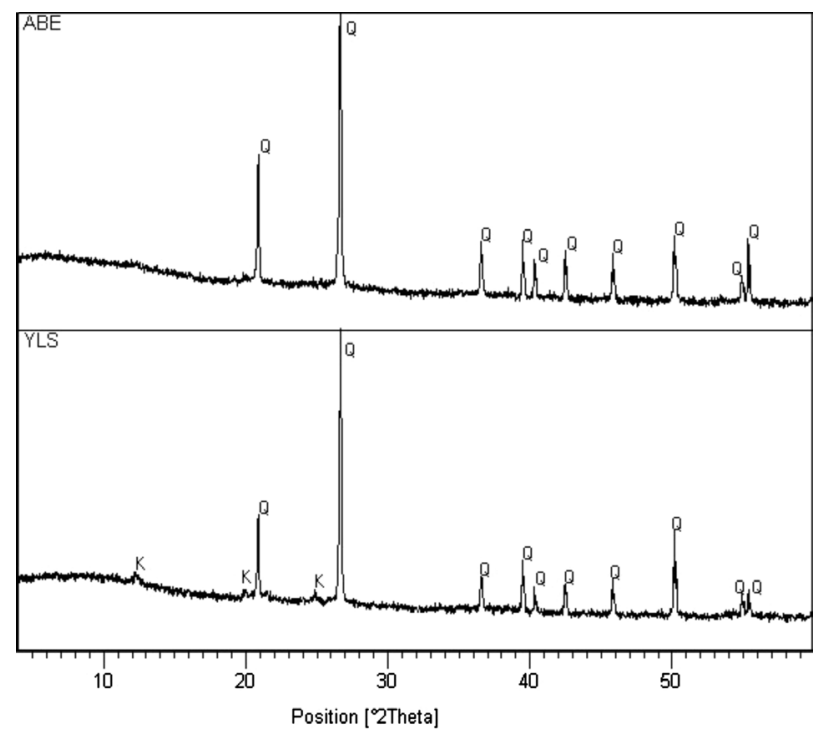

Figure 3. XRD pattern for the archaeological black earth (ABE) and yellow Latossolos surrounding (YLS) from Ilha de Terra-Caxiuanã. Symbols: $\mathrm{Q}=$ quartz, $\mathrm{K}$ = kaolinite.

Table 1. Physical and chemical properties of the ABE soil profile and YLS soil profile. Concentrations of organic matter $(\mathrm{OM}), \mathrm{Ca}^{2+}, \mathrm{Mg}^{2+}$, available $\mathrm{P}$ in $\mathrm{mg} \mathrm{kg}{ }^{-1}$; coarse sand, fine sand, silt, clay, $\mathrm{OM}, \mathrm{SiO}_{2}, \mathrm{Al}_{2} \mathrm{O}_{3}$ and $\mathrm{Fe}_{2} \mathrm{O}_{3}$ in $\mathrm{g} \mathrm{kg}^{-1}$

\begin{tabular}{|c|c|c|c|c|c|c|c|c|c|c|c|c|c|}
\hline Horizons & C. $S^{b}$ & F.S ${ }^{c}$ & Silt & Clay & $\mathrm{pH}\left(\mathrm{H}_{2} \mathrm{O}\right)$ & $\mathrm{pH}(\mathrm{KCl})$ & $\mathrm{OM}$ & $\mathrm{SiO}_{2}$ & $\mathrm{Al}_{2} \mathrm{O}_{3}$ & $\mathrm{Fe}_{2} \mathrm{O}_{3}$ & $\mathrm{P}$ & $\mathrm{Ca}^{2+}$ & $\mathrm{Mg}^{2+}$ \\
\hline ABE-A $A_{1}$ & 560 & 190 & 190 & 60 & 4.5 & 3.83 & 171 & 783.6 & 73.8 & 18.5 & 135 & 1708 & 158 \\
\hline $\mathrm{ABE}-\mathrm{A}_{2}$ & 560 & 160 & 200 & 80 & 4.9 & 3.89 & 126 & 737.1 & 75.7 & 19.6 & 96 & 984 & 127 \\
\hline $\mathrm{ABE}-\mathrm{A}_{3}$ & 530 & 170 & 210 & 90 & 5.11 & 4.18 & 77 & 718.5 & 79.1 & 22.1 & 127 & 648 & 67 \\
\hline ABE-AB & 520 & 170 & 220 & 90 & 5.26 & 4.38 & 27 & 704.3 & 98.6 & 29.8 & 99 & 520 & 31 \\
\hline ABE-BA & 500 & 150 & 230 & 120 & 5.26 & 4.36 & 25 & 698.4 & 98.8 & 34.6 & 69 & 480 & 24 \\
\hline${\mathrm{ABE}-\mathrm{B}_{1}}_{1}$ & 470 & 140 & 230 & 160 & 5.36 & 4.61 & 20 & 685.7 & 111.6 & 38.1 & 79 & 220 & 22 \\
\hline $\mathrm{ABE}^{-\mathrm{B}_{2}}$ & 440 & 110 & 240 & 210 & 5.59 & 4.79 & 12 & 678.8 & 142.5 & 40.3 & 100 & 232 & 22 \\
\hline $\mathrm{ABE}^{-B_{3}}$ & 420 & 110 & 240 & 230 & 5.87 & 4.91 & 8 & 665.0 & 150.2 & 50.8 & 88 & 84 & 19 \\
\hline YLS-A 1 & 470 & 200 & 150 & 180 & 4.06 & 3.60 & 2 & 705.0 & 93.4 & 30.5 & 18 & 20 & 7.2 \\
\hline YLS-AB & 440 & 180 & 170 & 210 & 4.13 & 3.73 & 1.8 & 681.3 & 124.6 & 45.8 & 17 & 20 & 7.2 \\
\hline YLS-BA & 410 & 170 & 180 & 240 & 4.22 & 4.00 & 1.6 & 659.2 & 152.8 & 51.0 & 13 & 20 & 4.8 \\
\hline YLS-B $_{1}$ & 390 & 170 & 180 & 260 & 4.24 & 4.02 & 1.2 & 651.3 & 162.9 & 53.6 & 48 & 16 & 4.8 \\
\hline YLS-B ${ }_{2}$ & 390 & 130 & 190 & 290 & 4.46 & 4.05 & 1.2 & 636.4 & 178.1 & 67.2 & 48 & 12 & 4.8 \\
\hline $\mathrm{YLS}_{3} \mathrm{~B}_{3}$ & 370 & 110 & 220 & 300 & 4.58 & 4.05 & 0.8 & 632.0 & 197.2 & 79.3 & 51 & 12 & 4.8 \\
\hline
\end{tabular}

${ }^{\mathrm{a} P-M e h l i c h-1 ; ~}{ }^{\mathrm{b} C o a r s e}$ sand; ${ }^{\mathrm{C}}$ Fine sand. 
minerals in both soil profiles. The concentrations of kaolinite increases with depth in both profiles, being more pronounced in the YLS profile. Goethite has a lower concentration than that of kaolinite and quartz in all profiles. The horizon $\mathrm{A}$ of the $\mathrm{ABE}$ profile has a higher concentration in $\mathrm{SiO}_{2}$ and $\mathrm{OM}$ as well as lower concentrations of $\mathrm{Al}_{2} \mathrm{O}_{3}$ and $\mathrm{Fe}_{2} \mathrm{O}_{3}$ compared with those of the $\mathrm{A}$ horizon from the YLS profile. In both soil profiles, there is an increase of the $\mathrm{SiO}_{2} / \mathrm{Al}_{2} \mathrm{O}_{3}$ ratio toward the surface, with the increase in the $\mathrm{ABE}$ profile greater than in the YLS profile. The increase in the $\mathrm{SiO}_{2} / \mathrm{Al}_{2} \mathrm{O}_{3}$ ratio indicates that the soils have lost $\mathrm{Al}_{2} \mathrm{O}_{3}$, resulting in an accumulation of quartz.

Figures 4 and 5 show the variability of the concentrations of OM compared with other chemical properties (available $\mathrm{P}$ and exchangeable $\mathrm{Ca}^{2+}$ and $\mathrm{Mg}^{2+}$ ) along the soils profiles. In the $\mathrm{ABE}$ soil profile are observed increase in the concentrations of $\mathrm{Ca}$ with those of $\mathrm{OM}$; small variability in the concentrations of $\mathrm{Mg}$ and P. In the YLS soil profile was observed higher concentrations of $\mathrm{OM}$ in the horizons $\mathrm{AB}$, $\mathrm{BA}$ and $\mathrm{B}_{1}$ and of $\mathrm{P}$ in the horizons $\mathrm{B}_{1}$ to $\mathrm{B}_{3}$; slight increase in $\mathrm{Ca}$ concentrations towards the surface. The greater $\mathrm{pH}$ in the A horizon from the ABE profile and ABE area compared with those of the YLS (Table 1) is the result of higher base cation saturation of the cation exchange. This feature was observed in each site and might be the result of base cation inputs during site habitation. ${ }^{21} \mathrm{pH}$ has a further importance because it can determine a variety of nutrient transformation and toxicity relationships in soils. ${ }^{7}$

These data show that the values for $\mathrm{pH}$ and $\mathrm{OM}$, available $\mathrm{P}$ and exchangeable $\mathrm{Ca}^{2+}$ and $\mathrm{Mg}^{2+}$ concentrations in $\mathrm{ABE}$ are compatible with those obtained from other sites in the Caxiuanã region. ${ }^{21}$ It was estimated from the difference between $\mathrm{pH}\left(\mathrm{H}_{2} \mathrm{O}\right)$ and $\mathrm{pH}(\mathrm{KCl})$ that the $\mathrm{ABE}$ and YLS soils from Ilha de Terra presents $\triangle \mathrm{pH}$ between -1.08 to -1.09 and -0.52 to -1.31 , respectively. Surface charge is usually determined by the difference between $\mathrm{pH}_{\mathrm{ZPC}}$, the point of zero charge, and the actual soil $\mathrm{pH}$, such that if $\mathrm{pH}_{\mathrm{ZPC}}-\mathrm{pH}$ is negative then the surface charge is negative. ${ }^{32-35}$

Considering the mineralogical and chemical properties of the soils from Ilha de Terra, it has been suggested that they have a negative charge and that OM is mainly responsible for this development. Quartz, anatase, goethite and hematite contain a negligible charge. ${ }^{36}$ The tetrahedral sheet of kaolinite carries a small permanent negative charge because of isomorphous substitution of $\mathrm{Si}^{4+}$ by $\mathrm{Al}^{3+}$, leaving a single negative charge for each substitution. Both the octahedral sheet and the crystal edges have a dependent variable charge caused by the protonation and deprotonation of surface hydroxyl ( $\mathrm{SOH}$ ) groups. Thus, tetrahedral sites of clay become permanently negatively

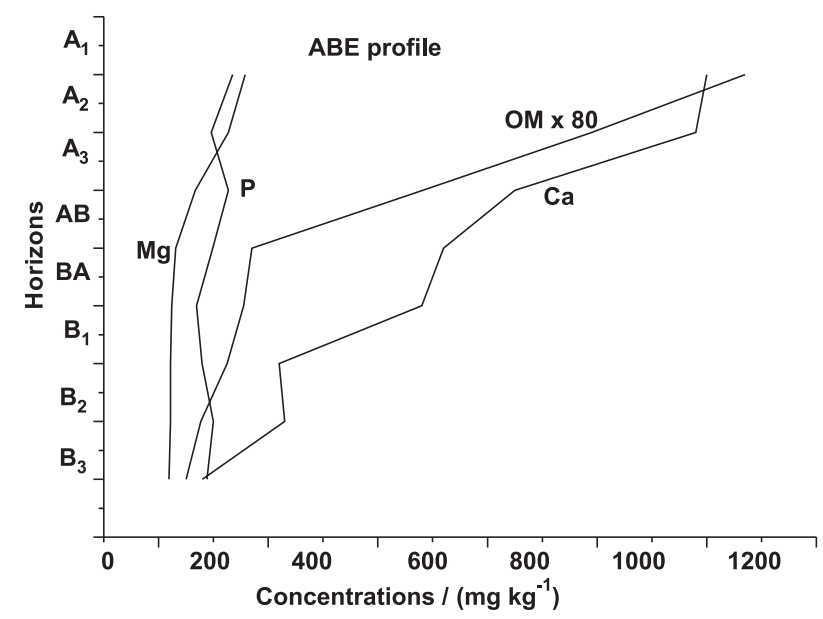

Figure 4. Concentrations of organic matter (OM) compared with other chemical properties along the horizons of the ABE soil profile.

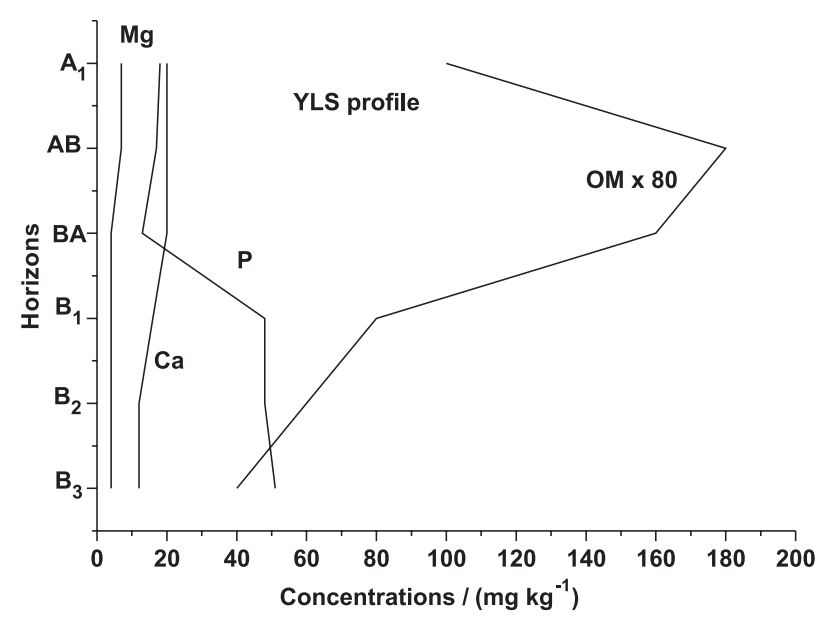

Figure 5. Concentrations of organic matter (OM) compared with other chemical properties along the horizons of the YLS soil profile.

charged and allow the electrostatic interaction with positively charged ions. However, this permanent charge is a minor component in kaolinite-type clays. The layer edges where exposed $\mathrm{OH}$ groups will exhibit acid-base behavior are primarily responsible for the interaction of kaolinite with environmental metal ions. Crystalline oxide of iron (hematite) is widely distributed in soils and has a surface that is normally hydrated so it can participate in adsorption reactions similar to those of hydrous. Soil $\mathrm{pH}_{\mathrm{ZPC}}$ can be altered by adding OM. ${ }^{36}$ Therefore, the appropriate manipulation of the soils can lead to an increase in surface negative charge. ${ }^{32}$

\section{Geochemical dispersion}

The release and retention of $\mathrm{OM}, \mathrm{Ca}, \mathrm{Mg}$ and $\mathrm{P}$ in soils with $\mathrm{ABE}$ is a dynamic process that is dependent on the $\mathrm{pH}$ and mineralogy of the soils and chemistry composition of the soils solution. The variability of these properties in the area 
$\mathrm{ABE}$ is reflected through the concentrations (Tables 2 and 3) and variances (Table 4). $\mathrm{OM}$ and $\mathrm{Ca}$ are the components of soils that have a higher dispersion in all directions from the $\mathrm{ABE}$ area (north, south, central, north-south and east-west). Values of variance indicate that the dispersion of $\mathrm{P}$ and $\mathrm{Mg}$ are also important but are much lower than those obtained for $\mathrm{OM}$ and $\mathrm{Ca}$. The highest concentrations of $\mathrm{OM}$ were observed in the southwest and northwest and the lowest in the northeast and southeast of the ABE area. In some places in $\mathrm{ABE}$ area, a sharp decrease in the concentrations of $\mathrm{Ca}$ and $\mathrm{OM}$ were observed, for example in the central area, north-south and east-west (Figures 6 and 7). It is possible that the spaces in the area with the lowest concentrations of $\mathrm{OM}$ and $\mathrm{Ca}$ have been used by ancient inhabitants as preferential sites for religious ceremonies, the spaces with highest concentrations of $\mathrm{OM}$ and $\mathrm{Ca}$ have been used as preferential sites for food preparation and the accumulation of waste and a small area with high concentrations of $\mathrm{Ca}, \mathrm{Mg}$ and $P$ has been reserved as a cemetery. Many Indian villages have a cleared space in the central area that is kept clean for

Table 2. Chemical properties from soils with archaeological Black earth along N-S area

\begin{tabular}{lcccccccccc}
\hline$(\mathrm{N}-\mathrm{S})$ & & $\mathrm{Ph}$ & & $\mathrm{OM} /\left(\mathrm{mg} \mathrm{kg}^{-1} \times 10^{3}\right)$ & \multicolumn{2}{c}{$\mathrm{Ca} /\left(\mathrm{mg} \mathrm{kg}^{-1}\right)$} & \multicolumn{2}{c}{$\mathrm{Mg} /\left(\mathrm{mg} \mathrm{kg}^{-1}\right)$} & \multicolumn{2}{c}{$\mathrm{P} /\left(\mathrm{mg} \mathrm{kg}^{-1}\right)$} \\
\hline$(\mathrm{m})$ & $\mathrm{A}_{1}$ & $\mathrm{~A}_{2}$ & $\mathrm{~A}_{1}$ & $\mathrm{~A}_{2}$ & $\mathrm{~A}_{1}$ & $\mathrm{~A}_{2}$ & $\mathrm{~A}_{1}$ & $\mathrm{~A}_{2}$ & $\mathrm{~A}_{1}$ & $\mathrm{~A}_{2}$ \\
50 & 4.44 & 4.72 & 86 & 70 & 300 & 200 & 156 & 120 & 250 & 220 \\
40 & 4.16 & 4.38 & 76 & 76 & 540 & 440 & 126 & 120 & 274 & 422 \\
35 & 4.47 & 4.61 & 92 & 76 & 710 & 600 & 102 & 108 & 296 & 392 \\
20 & 4.52 & 4.66 & 83 & 62 & 800 & 540 & 132 & 120 & 333 & 391 \\
10 & 4.21 & 4.44 & 73 & 71 & 610 & 460 & 110 & 96 & 378 & 447 \\
0 & 4.02 & 4.5 & 86 & 80 & 490 & 440 & 110 & 132 & 356 & 435 \\
10 & 4.03 & 4.04 & 83 & 94 & 600 & 600 & 84 & 50 & 410 & 460 \\
20 & 4.26 & 4.45 & 145 & 123 & 580 & 580 & 140 & 70 & 350 & 475 \\
\hline
\end{tabular}

Table 3. Chemical properties from soils with archaeological Black earth along W-E area

\begin{tabular}{lcccccccccc}
\hline W-E & & $\mathrm{pH}$ & \multicolumn{2}{c}{$\mathrm{OM} /\left(\mathrm{mg} \mathrm{kg}^{-1} \times 10^{3}\right)$} & \multicolumn{2}{c}{$\mathrm{Ca} /\left(\mathrm{mg} \mathrm{kg}^{-1}\right)$} & \multicolumn{2}{c}{$\mathrm{Mg} /\left(\mathrm{mg} \mathrm{kg}^{-1}\right)$} & \multicolumn{2}{c}{$\mathrm{P} /\left(\mathrm{mg} \mathrm{kg}^{-1}\right)$} \\
\hline$(\mathrm{m})$ & $\mathrm{A}_{1}$ & $\mathrm{~A}_{2}$ & $\mathrm{~A}_{1}$ & $\mathrm{~A}_{2}$ & $\mathrm{~A}_{1}$ & $\mathrm{~A}_{2}$ & $\mathrm{~A}_{1}$ & $\mathrm{~A}_{2}$ & $\mathrm{~A}_{1}$ & $\mathrm{~A}_{2}$ \\
40 & 4.83 & 4.70 & 108.0 & 96.80 & 1036 & 620 & 129 & 116 & 541 & 418 \\
30 & 4.54 & 4.55 & 142.4 & 108.6 & 545 & 420 & 99 & 106 & 521 & 390 \\
20 & 4.48 & 4.51 & 104.0 & 107.2 & 600 & 389 & 147 & 120 & 533 & 467 \\
10 & 4.41 & 4.42 & 90.00 & 87.00 & 503 & 340 & 141 & 113 & 484 & 419 \\
00 & 4.47 & 4.30 & 78.00 & 70.64 & 497 & 356 & 93 & 92 & 525 & 348 \\
10 & 4.36 & 4.41 & 65.60 & 58.84 & 411 & 289 & 113 & 78 & 423 & 365 \\
20 & 4.16 & 4.47 & 50.80 & 75.60 & 332 & 230 & 110 & 80 & 380 & 228 \\
30 & 4.26 & 4.41 & 74.48 & 69.60 & 255 & 320 & 130 & 106 & 358 & 284 \\
40 & 4.10 & 4.28 & 94.00 & 93.30 & 95 & 274 & 102 & 93 & 367 & 236 \\
\hline
\end{tabular}

Table 4. Variance of chemical properties from $\mathrm{ABE}$ areas north, south, central, north-south and west-east, as $\mathrm{ABE}_{\mathrm{N}}, \mathrm{ABE}_{\mathrm{S}}, \mathrm{ABE}_{\mathrm{CENTRAL}}, \mathrm{ABE}_{\mathrm{N}-\mathrm{S}}$ and $\mathrm{ABE}_{\mathrm{W}-\mathrm{E}}$, respectively

\begin{tabular}{|c|c|c|c|c|c|c|c|c|c|c|}
\hline \multicolumn{11}{|l|}{ Variance } \\
\hline \multirow[t]{2}{*}{ ABE Area } & \multicolumn{2}{|c|}{$\mathrm{pH}$} & \multicolumn{2}{|c|}{$\mathrm{OM}$} & \multicolumn{2}{|c|}{$\mathrm{Ca}$} & \multicolumn{2}{|c|}{$\mathrm{Mg}$} & \multicolumn{2}{|c|}{$\mathrm{P}$} \\
\hline & $\mathrm{A}_{1}$ & $\mathrm{~A}_{2}$ & $\mathrm{~A}_{1}$ & $\mathrm{~A}_{2}$ & $\mathrm{~A}_{1}$ & $\mathrm{~A}_{2}$ & $\mathrm{~A}_{1}$ & $\mathrm{~A}_{2}$ & $\mathrm{~A}_{1}$ & $\mathrm{~A}_{2}$ \\
\hline $\mathrm{ABE}_{\mathrm{N}}$ & 128 & 99 & $1 \times 10^{9}$ & 381 & 40254 & 22690 & 654 & 113 & 2629 & 1604 \\
\hline $\mathrm{ABE}_{\mathrm{S}}$ & 32 & 7 & 969 & 752 & 2128 & 25400 & 12357 & 10978 & 9398 & 12424 \\
\hline $\mathrm{ABE}_{\text {CENTRAL }}$ & 13 & 15 & 1429 & 987 & 156592 & 7441 & 1790 & 2694 & 10312 & 26998 \\
\hline $\mathrm{ABE}_{\mathrm{N}-\mathrm{S}}$ & 18 & 20 & $5 \times 10^{8}$ & $9 \times 10^{8}$ & 22098 & 18914 & 528 & 750 & 2925 & 6651 \\
\hline $\mathrm{ABE}_{\mathrm{W}-\mathrm{E}}$ & 22 & 20 & $8 \times 10^{8}$ & $3 \times 10^{8}$ & 69232 & 12924 & 371 & 236 & 5903 & 7142 \\
\hline
\end{tabular}




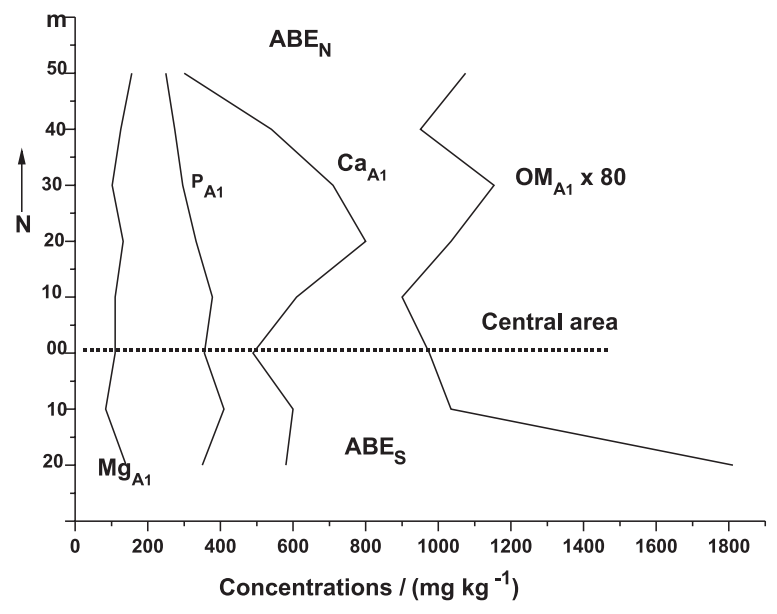

Figure 6. Concentrations of the available $\mathrm{P}$, exchangeable $\mathrm{Ca}^{2+}$ and $\mathrm{Mg}^{2+}$ and OM (multiplied by 80 ) in north to south of the area $\left\{(\mathrm{ABE})_{\mathrm{N}-\mathrm{S}}\right\}$.

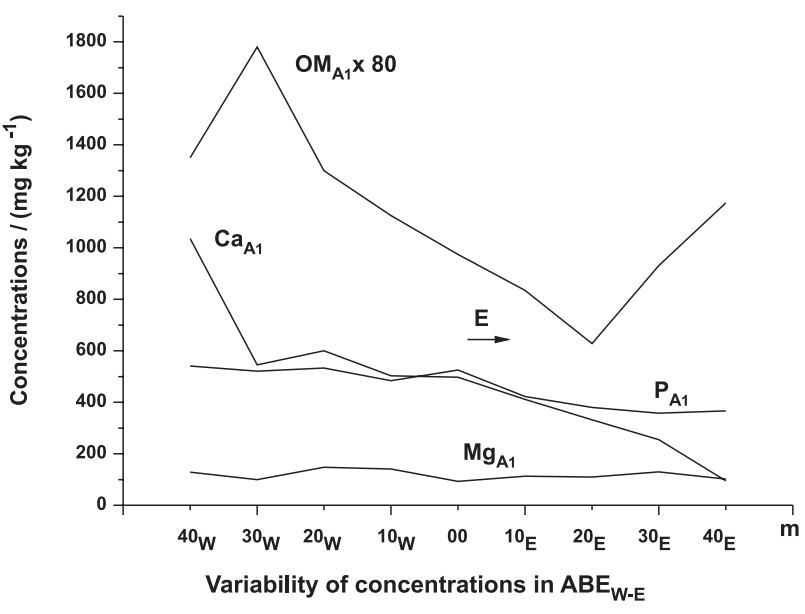

Figure 7. Concentrations of the available $\mathrm{P}$, exchangeable $\mathrm{Ca}^{2+}$ and $\mathrm{Mg}^{2+}$ and $\mathrm{OM}$ (multiplied by 80 ) in west-east area $\left\{(\mathrm{ABE})_{\mathrm{W}-\mathrm{E}}\right\}$.

Table 5. Correlation matrix of chemical properties from soils with archaeological Black earth from ABE area N-S

\begin{tabular}{|c|c|c|c|c|c|c|c|c|c|c|c|c|c|c|c|c|}
\hline & \multicolumn{4}{|c|}{$(\mathrm{ABE})_{\mathrm{N}}: 50_{\mathrm{N}}$} & \multicolumn{4}{|c|}{$(\mathrm{ABE})_{\mathrm{N}}: 40_{\mathrm{N}}$} & \multicolumn{4}{|c|}{$(\mathrm{ABE})_{\mathrm{N}}: 30_{\mathrm{N}}$} & \multicolumn{4}{|c|}{$(\mathrm{ABE})_{\mathrm{N}}: 20_{\mathrm{N}}$} \\
\hline & $\mathrm{OM}$ & $\mathrm{P}$ & $\mathrm{Ca}$ & $\mathrm{Mg}$ & $\mathrm{OM}$ & $\mathrm{P}$ & $\mathrm{Ca}$ & $\mathrm{Mg}$ & $\mathrm{OM}$ & $\mathrm{P}$ & $\mathrm{Ca}$ & $\mathrm{Mg}$ & $\mathrm{OM}$ & $\mathrm{P}$ & $\mathrm{Ca}$ & $\mathrm{Mg}$ \\
\hline $\mathrm{OM}$ & 1 & & & & 1 & & & & 1 & & & & 1 & & & \\
\hline $\mathrm{P}$ & 0.2 & 1 & & & 0.3 & 1 & & & 0.01 & 1 & & & 0.01 & 1 & & \\
\hline $\mathrm{Ca}$ & 0.3 & 0.41 & 1 & & 0.6 & 0.5 & 1 & & 0.01 & 0.5 & 1 & & 0.6 & 0.3 & 1 & \\
\hline \multirow[t]{3}{*}{$\mathrm{Mg}$} & 0.3 & 0.1 & 0.2 & 1 & 0.3 & 0.3 & 0.4 & 1 & 0.01 & 0.2 & 0.6 & 1 & 0.5 & 0.2 & 0.5 & 1 \\
\hline & \multicolumn{4}{|c|}{$(\mathrm{ABE})_{\mathrm{N}}: 10_{\mathrm{N}}$} & \multicolumn{4}{|c|}{ ABN: central } & \multicolumn{4}{|c|}{$(\mathrm{ABE})_{\mathrm{S}}: 10_{\mathrm{S}}$} & \multicolumn{4}{|c|}{$(\mathrm{ABE})_{\mathrm{s}}: 20_{\mathrm{s}}$} \\
\hline & $\mathrm{OM}$ & $\mathrm{P}$ & $\mathrm{Ca}$ & $\mathrm{Mg}$ & $\mathrm{OM}$ & $\mathrm{P}$ & $\mathrm{Ca}$ & $\mathrm{Mg}$ & $\mathrm{OM}$ & $\mathrm{P}$ & $\mathrm{Ca}$ & $\mathrm{Mg}$ & $\mathrm{OM}$ & $\mathrm{P}$ & $\mathrm{Ca}$ & $\mathrm{Mg}$ \\
\hline $\mathrm{OM}$ & 1 & & & & 1 & & & & 1 & & & & 1 & & & \\
\hline $\mathrm{P}$ & 0.1 & 1 & & & 0.1 & 1 & & & 0.4 & 1 & & & 0.4 & 1 & & \\
\hline $\mathrm{Ca}$ & 0.5 & 0.4 & 1 & & 0.6 & 0.1 & 1 & & 0.8 & 0.6 & 1 & & 0.3 & 0.2 & & \\
\hline $\mathrm{Mg}$ & 0.6 & 0.2 & 0.8 & 1 & 0.2 & 0.3 & 0.5 & 1 & 0.3 & 0.01 & 0.5 & 1 & 0.2 & 0.01 & 0.01 & 1 \\
\hline
\end{tabular}

ceremonial events whereas rubbish is commonly deposited at the perimeter of the ancient settlement. ${ }^{9}$

\section{Geochemical correlation}

The similarities and differences among the distribution patterns of $\mathrm{OM}, \mathrm{Ca}, \mathrm{P}$ and $\mathrm{Mg}$ can be estimated through the correlation coefficients shown in Table 5. The highest correlation coefficients were obtained between pairs OM-Ca and Ca-Mg. However, it has been shown that the interpretation of element concentrations patterns in archaeological soils is problematic because of the complexity of site use history and the effects of postdepositional soil processes. Many human activities can add element loadings to cultivated soils. However, a host of natural and anthropogenic factors can affect total soil concentrations. Background variation linked to differences in soils can result in patterns of element concentration unconnected to the archaeology. ${ }^{1}$

\section{Conclusions}

The physicochemical properties of the soil profiles ABE and YLS suggested the soils of these profiles belonged to the same class of soil before human occupation. The activities performed by the ancient inhabitants of the region caused changes in the upper horizons of that soil class. This hypothesis is shown in this study through the following data: changing of the yellow color of Latossolos to black, dark brown and light brown because of the presence of black carbon and the accumulation of OM originated from animal and vegetable waste; changing of the soil texture from sandy-clay to sandy because of human settlement, which decreased the concentrations of $\mathrm{Al}$ and increased those of $\mathrm{Si}$ due to the formation of quartz; lower concentrations of $\mathrm{OM}$, exchangeable $\mathrm{Ca}^{2+}$ and $\mathrm{Mg}^{2+}$ and available $\mathrm{P}$ in the spaces near the central area suggesting that these spaces were reserved for religious ceremonies or other events. 


\section{Acknowledgments}

This study was made possible by sampling support of the Museu Paraense Emilio Goeldi and financial support of the Conselho Nacional de Desenvolvimento Científico e Tecnológico (CNPq).

\section{References}

1. Wilson, C. A.; Davidson, D. A.; Cresser, M. S.; J. Archaeol. Sci. 2008, 35, 412.

2. Parnell, J. J.; Terry, R. E.; J. Archaeol. Sci. 2002, 29, 379.

3. Fernandez, F. G.; Terry, R. E.; Inomate, T.; Eberl, M.; Geoarchaeology 2002, 17, 487.

4. Lima, H. N.; Schaefer, C. E. R.; Melo, J. W. V.; Gilkes, R. J.; Ker, J. C.; Geoderma 2002, 110, 1.

5. Cunha, T. J. F.; Madari, B. E.; Canellas, L. P.; Ribeiro, L. P.; Benites, V. M.; Santos, G. A.; R. Bras. Ci. Solo 2009, 35, 85.

6. Lehmann, J.; Kern, D.; German, L.; Mccann, J.; Martins, G. C.; Moreira, A. In Amazonian Dark Earths: Origin, Properties, Management; Lehmann, J.; Kern, D. C.; Glaser, B.; Woods, W. I., eds.; Kluwer Academic Publishers: Boston-London, 2003, ch. 6.

7. Falcão, N. P. S.; Comerford, N.; Lehmann, J. In Amazonian Dark Earths: Origin, Properties, Management; Lehmann, J.; Kern, D. C.; Glaser, B.; Woods, W. I., eds.; Kluwer Academic Publishers: Boston-London, 2003, ch.14.

8. Novotny, E. H.; Hayes, M. H. B.; Madari, B. E.; Bonagamba, T. J.; Azevedo, E. R.; Souza, A. A.; Song, G.; Nogueira, C. M.; Mangrich, A. S.; J. Braz. Chem. Soc. 2009, 20, 1003.

9. Smith, N. J. H.; Annals of the Association of American Geographers 1980, 70, 553.

10. German, L. A.; Geoderma 2003, 111, 307.

11. Woods, W. I.; McCann, J. M. Yearbook Conference of Latin Americanist Geographers, 1999.

12. Woods, W. I.; McCann, J. M.; Meyer, D. W. Schoolmaster, F. A. Papers and Proceedings of the Applied Geography Conferences, 2000.

13. Kern, D. C.; Kämpf, N. R.; R. Bras. Ci. Solo 1989, 13, 219.

14. Kämpf, N. R.; Woods, W. I.; Sombroek, W.; Kern, D. C.; Cunha, T. J. F. In Amazonian Dark Earths: Origin, Properties, Management; Lehmann, J.; Kern, D. C.; Glaser, B.; Woods, W. I., eds.; Kluwer Academic Publishers: Boston-London, ch. 5 .

15. Haumaier, L.; Zech, W.; Org. Geochem. 1995, 23, 191.

16. Glaser, B.; Haumaier, L.; Guggenberg, G.; Zech, W.; Org. Geochem. 1998, 29, 811.

17. Golchin, A.; Baldock, J. A.; Clarke, P.; Higashi, T.; Oades, J. M.; Geoderma 1997, 76, 175.

18. Ribeiro, L. G. L.; Carreira, R. S.; Wagener, A. L. R.; J. Braz. Chem. Soc. 2008, 19, 1277.
19. Neves, E. G.; Petersen, J. B.; Bartone, R. N.; Silva, C. A. In Amazonian Dark Earths: Origin, Properties, Management; Lehmann, J.; Kern, D. C.; Glaser, B.; Woods, W. I., eds.; Kluwer Academic Publishers: Boston-London, 2003, ch.3.

20. Kern, D. C.; D’aquino, G.; Rodrigues, T. E.; Frazão, F. J.; Sombroek, W.; Myers, T. P.; Neves, E. G. In Amazonian Dark Earths: Origin, Properties, Management; Lehmann, J.; Kern, D. C.; Glaser, B.; Woods, W. I., eds.; Kluwer Academic Publishers: Boston-London, 2003, ch. 4.

21. Costa, M. L.; Kern, D. C.; J. Geochem. Explor. 1999, 66, 369.

22. Lemos, A.; Santos, P. B.; Manual de Descrição e Coleta de Solos em Campo; Sociedade Brasileira de Ciência do Solo: Viçosa, Brasil, 2002.

23. Munsell Colors Company; Munsell Soil Colors Charts, Baltimore, 2000.

24. Soil Survey Staff, National Soil Survey Laboratory; Methods Manual: Soil Survey Investigations Report 42, version 4.0; United States Department of Agriculture, Natural Resources Conservation Service, National Soil Survey Center, US Govt print Office: Washington, DC, 2004.

25. Shriver, D. F.; Atkins, P. W.; Quimica Inorgânica, Bookman: São Paulo, Brasil, 2008.

26. Stumm, W.; Morgan, J. J.; Aquatic Chemistry. Chemical Equilibria and Rates in Natural Waters, John Wiley \& Sons: New York, 1996.

27. Schmidt, M. W. I.; Heike, K. H.; Kögel-Knabner, I.; Org. Geochem. 2000, 31, 727.

28. Glaser, B.; Balashov, E.; Haumaier, L.; Guggenberger, G.; Zech, W.; Org. Geochem. 2000, 31, 669.

29. Brodowski, S.; Rodionov, A.; Haumaier, L.; Glaser, B.; Amelung, W.; Org. Geochem. 2005b 36, 1299.

30. Brodowski, S.; John, B.; Flessa, H.; Amelung, W.; Eur. J. Soil Sci. 2006, 59, 539.

31. Brodowski, S.; Amelung, W.; Haumaier, L.; Zech, W.; Geoderma 2007, 139, 220.

32. Van Ranst, E.; Shamshuddin, J.; Baert, G.; Dzwowa, P. K.; Eur. J. Soil Sci. 1998, 49, 243.

33. Gilman, G. P.; Aust. J. Soil Res. 1985, 23, 643.

34. Gilman, G. P.; Sumpter, E. A.; Aust. J. Soil Res. 1986, 24, 173.

35. Kaiser, K.; Guggenberger, G.; Org. Geochem. 2000, $31,71$.

36. Anderson, S. J.; Sposito, G.; Soil Sci. Soc. Am. J.; 1991, 55, 1569.

37. Kennedy, J.; Billett, M. F.; Duthie, D.; Fraser, A. R.; Harrison, A. F.; Eur. J. Soil Sci. 1996, 47, 625.

Submitted: April 6, 2010 Published online: January 27, 2011 